\title{
THE DEATH PENALTY IN MAGDEBURGIAN CITIES OF THE GRAND DUCHY OF LITHUANIA IN THE LATE- 16TH AND EARLY-17TH CENTURY ${ }^{1}$
}

\author{
Gitana Zujienè
}

ABSTRACT In the article, based on the acts of Magdeburg Law and the court books of Magdeburgian cities, the issue of the death penalty in Magdeburgian cities of the Grand Duchy of Lithuania is analysed. The most often imposed death penalties are discussed. There is an analysis of which crimes they were given for. Their use is compared with data from Poland and some Magdeburgian cities in Western Europe.

Along with baptism, German city, or Magdeburg, Law came to the Grand Duchy of Lithuania. Lithuania's capital Vilnius ${ }^{2}$ received such a charter first, following the example of Cracow, on 22 March 1387. Soon afterwards, it was given to Brest, ${ }^{3}$ Kaunas, ${ }^{4}$ and perhaps Trakai. ${ }^{5}$ By the middle of the 17 th century, several dozen cities in the grand duchy used it. The charter was granted to smaller cities following the example of larger ones. For example, on 26 July 1531, the privilege was given to Voine on the example of Brest, ${ }^{6}$ in 1616 to Joniškis on the example of the Magdeburgian city of Kaunas. ${ }^{7}$

${ }^{1}$ This article is prepared in fulfilling the Research Council of Lithuania within the framework of the 'National Lithuanian Studies Development Programme for 2009-2015' funded project 'The Death Penalty in the Grand Duchy of Lithuania in the 14th to the Early-17th Century: Theory and Practice' (LIT-5-18).

${ }^{2}$ P. Dubinski, Zbior praw prywilejow miastu stolecznemu W. X. L. Wilnowi nadanych (Wilno, 1788), s. 1-2.

${ }^{3}$ Akty litovsko-russkogo gosudarstva (1390-1529), ed. M. Dovnar-Zapolskii (Moscow, 1899), vyp. 1, nr. 1, p. 1-2.

${ }^{4}$ Z. Kiaupa, '1408 m. Vytauto privilegija Kauno miestui', Lietuvos istorijos metraštis (hereafter - LIM) 1979 metai (1981), p. 16.

5 A. Baliulis, 'Trakų miesto privilegijos (Lietuvos Metrikos duomenimis)', Lietuvos miestu istorijos šaltiniai (hereafter - LMIŠ), kn. 2, ed. Z. Kiaupa, E. Rimša (Vilnius, 1992), p. 40.

${ }^{6}$ Akty, otnosiashchesia $k$ istoriy Yugo-Zapadnoi Rossii, t. 1 (St Petersburg, 1863), pp. 80-81.

${ }^{7}$ Granting of Magdeburg rights to Joniškis, 4 July 1616, Lietuvos magdeburginiu miestu privilegijos ir aktai (hereafter - LMMPA), Joniškis, Jurbarkas, ed. A. Tyla, t. 1 (Vilnius, 1991), p. 143. 
The most important moment in granting the charter was the affirmation that the city was released from its dependence on Polish, Lithuanian and Russian law, and its executive courts of marshals, castellans, starostas and governors, and transferred to German law, the main actors of which were the voigt (vaitas) and the benchers (suolininkai), and the burgomaster and the Council. The main sources of these rights were the law of the Saxon land, the Saxon mirror (Speculum Saxorum, Landrecht), and the law of the Saxon city (Jus Municipale, Weichbildrecht). However, Magdeburg Law, created in the 13th century, was not a homogeneous legal code. During its expansion into Western, Central and Eastern Europe, it evolved in somewhat different ways. For example, in Poland, in the opinion of Jolanta Karpavičiene, after the fusion of elements of Saxon, Polish and Roman law, in the 16th century there appeared a Polish version of Magdeburg Law, the content of which was very distant from the texts of 13th-century German law. ${ }^{8}$ Similar things also happened in the Grand Duchy of Lithuania. Zigmantas Kiaupa indicates that the local government institutions and courts of Lithuanian cities not only used the Latin and German acquis of this law, but adapted the law to Lithuanian conditions. ${ }^{9}$

Only quite recently, in the historiography of the Magdeburgian cities of the Grand Duchy of Lithuania, the main attention of researchers in the Lithuanian and the Polish and Belarusian languages, has turned to external features of Magdeburg Law. The spread of the network of Magdeburgian cities, ${ }^{10}$ the development of local authorities, the formation of the competencies of its officers, ${ }^{11}$ de-

8 J. Karpavičienè, 'Magdeburgo teisè: ištakos ir transformacijos', LMIঙ̌, t. 3 (Vilnius, 2001), p. 220.

9 Z. Kiaupa, 'Lietuvos miestų savivalda XIV-XVIII a.', Lietuvos heraldika, t. 1, ed. E. Rimša (Vilnius, 1998), p. 164.

${ }^{10}$ Z.Y. Kopyskii, 'Magdeburgskoe pravo v gorodakh Belorussii (konec XV pervaia polovina XVII v.)', Sovetskoe slavianovedenne, Nr. 5, (1972); J. Bardach, 'Miasta na prawie magdeburskim w Wielkim Księstwie Litewskim od schyłku XIV do połowy XVII stulecia', Kwartalnyk historyczny, r. 87, z. 1 (1980), pp. 21-51; idem, 'Ustrój miast na prawie magdeburskim w Wielkim Księstwie Litewskim do połowy XVII wieku', O dawnej i niedawnej Litwie (Poznań, 1988), pp. 72-119; Z. Kiaupa, 'Miestai', Lietuvos Didžiosios Kunigaikštijos kultūra. Tyrinejimai ir vaizdai, ed. V. Ališauskas et. al. (Vilnius, 2001), pp. 351-364; N.V. Misarevič, Magdeburgskije prava na Belarusi (Grodno, 2003).

11 Z. Kiaupa, 'Vilniaus ir Kauno vaitų teisminès galios raida XV-XVII amžiais', $M A D A$, t. 4 (1974), pp. 83-90; idem, 'Vaito rinkimas Kauno magistrate (XVI-XVIII a.)', LIM 1974 metai (1976), pp. 13-18; idem, '1551 m. ir 1620 m. Vilniaus vilkieriai ir jų taikymas Lietuvos Didžiosios Kunigaikštystès miestuose’, 
voting most attention to the major cities, were studied. Also studied was the symbolic expression of this law: the seals and heraldry of the cities. ${ }^{12}$ In recent decades, other topics have received more attention: the creation of guilds, ${ }^{13}$ the ruling elite of the cities, ${ }^{14}$ the problem of becoming a citizen ${ }^{15}$ and the situation of women in

Jaunuju istoriku darbai, kn. 1 (Vilnius, 1976), pp. 41-51; idem, 'Kauno savivaldos pradžia', Mokslas ir gyvenimas, no. 1 (1989), pp. 9-10; idem, 'Permainos Vilniaus savivaldoje XVI a. pirmojoje pusèje', Vilniaus savivaldai 610 metų: mokslinès konferencijos pranešimu tezès (Vilnius, 1997), pp. 2-3; idem, 'Kauno miesto savivalda 1408-1508 m.', Darbai ir dienos, no. 4 (1997), pp. 19-28; A. Ragauskas, 'Renkamos Vilniaus vaitijos genezè: XVI a. pabaiga ar XVII a. pradžia', Istorija, t. LVII (2003), pp. 26-35; A. Baliulis, 'Merkinès magistrato veikla XVI a. pabaigoje - XVII a. I pusejje’, Lituanistica t. 53, no. 3 (2007), pp. 1-12.

12 E. Rimša, 'Merkinès suolininkų teismo ir antspaudo atsiradimo klausimu', $L M I \check{S}$, ed. Z. Kiaupa and E. Rimša (Vilnius, 1988), pp. 141-146; idem, Kauno miesto herbas $X V-X X$ a. (Vilnius, 1994); the results of the research of the sphragistics and heraldry of cities for several decades are summarised - E. Rimša, Lietuvos Didžiosios Kunigaikštystès miestu antspaudai (Vilnius, 1999); idem, Heraldika. Iš praeities ị dabarti (Vilnius, 2004); idem, Pieczacie miast Wielkiego Księstwa Litewskiego (Warsaw, 2007); A. Tsitoŭ, Geral'dika belaruskikh mestaŭ (Minsk, 1998).

13 J. Morzy, Geneza i rozwój cechów wileńskich do końca XVII w. (Poznań, 1959); R. Urbaitytè, 'Kauno amatininkų cechų susikūrimas XVI-XVIII a.', Kauno istorijos metraštis (hereafter - KIM), t. 3 (2002), pp. 268-273.

${ }^{14}$ A. Ragauskas, 'Iš XVII a. Vilniaus miestiečių valdančiojo elito istorijos: Motiejus Vorbekas-Lettowas (1593-1663) ir jo „Atminties lobynas“", LIM 1996 metai (1997), pp. 5-42; idem, 'Vilniaus miestiečių valdančiojo elito dalyvavimas seimuose XVII a. antrojoje puseje', Lituanistica, no. 4 (1998), pp. 18-40; idem, 'Ką reiškè terminas “patricius” XVII a. Vilniuje?', Tarp istorijos ir būtovès. Studijos prof. Edvardo Gudavičiaus 70-mečiui, ed. A. Bumblauskas, R. Petrauskas (Vilnius, 1999), pp. 319-334; idem, Vilniaus miesto valdantysis elitas XVII a. antrojoje pusèje (1662-1702) (Vilnius, 2002); R. Varsackyte, 'Kauno miesto valdžios žmonės XVII-XVIII a. sandūroje', KIM, t. 5 (2004), pp. 7-8.

15 Z. Kiaupa, 'Miestietis, miesto pilietis ir miestelènas', Mokslas ir gyvenimas, no. 6 (1989), p. 31; A. Urbanavičius, 'Imigracija ị Vilnių iš Alytaus XVII a. 2-oje pusėje - XVIII a.', Alytaus miesto istorijos fragmentai, ed. A. Jakunskienè (Alytus, 2001), pp. 28-39; idem, 'Immigration to Vilnius from the Cities around the Baltic 1663-1795', Tagungen zur Ostmitteleuropa-Forschung, Band 21: Riga im Prozeß der Modernisierung: Studien zum Wandel einer Ostseemetropole im 19. und frühen 20. Jahrhundert (Marburg, 2004), pp. 10-25; idem, 'Iš Vilniaus miesto tarybos raštinès palikimo: naujujų miestiečių aktai 1663-1795', Lituanistica, no. 4 (2001), pp. 23-40; idem, Vilniaus naujieji miestiečiai 1661-1795 m. (Vilnius, 2005); idem, 'Kauniečių kilmès Vilniaus naujieji miestiečiai 1661-1795 m.', KIM, t. 7 (2006), pp. 23-41; idem, 'New Citizens of Vilnius 1661-1795', LHS, vol. 10 (2005), pp. 67-94; idem, Vilniaus naujieji miestiečiai 1661-1795 metais. Sąrašas (Vilnius, 2009); idem, 'The new citizens of Vilnius from Polish Royal Prussia', Europa Orientalis. Studia z dziejów Europy Wschodniej i państw Battyckich, 1 (Toruń, 2009), pp. 307-336. 
a Magdeburgian city. ${ }^{16}$ However, Lithuanian historians have paid only superficial attention to the application of Magdeburg rights in the practice of the courts of these cities. Therefore, the aim of this article is to draw attention to this blank spot in the history of the Magdeburgian courts of Lithuania, and to analyse the functioning of Magdeburg Law in criminal proceedings, initially limited to criminal offences that were subject to the death penalty. There will be an attempt to work out what kind of death penalty was imposed for what crime, and on what legal acts its application was based. It also examines whether the norms of Magdeburg Law coincided with their practical application, and discusses the question of the application of the death penalty.

Investigations into the death penalty in Magdeburgian cities of Europe are usually carried out in a wider context, investigating in a broad sense criminal law, the work of the courts, and everyday urban life, and death. ${ }^{17}$ In Poland, investigations into separate Magdeburgian cities, or investigations into penalties for specific crimes, are popular. For example, Witold Maisel studied mostly the application of criminal law in Poznan. ${ }^{18} \mathrm{He}$ also analysed the links between Magdeburg Law and the local law of Poland. ${ }^{19}$ Kristina Kamińska investigated the courts of Torun, analysing their work in the context of other cities in Poland and Germany. ${ }^{20}$ In fact, in this city, not Magdeburg, but Kulm city law operated. Marcin Kamler

${ }^{16}$ J. Karpavičienė, Moteris Vilniuje ir Kaune XVI a. pirmojoje pusejje. Gyvenimo sumiestinimo Lietuvoje atodangos (Vilnius, 2005).

${ }^{17}$ Crime and the Law. The Social History of Crime in Western Europe since 1500, ed. V. Gatrell, B. Lenman, G. Parker (London, 1980); J.A. Sharpe, Crime in Early Modern England 1550-1750 (London, 1984); R. van Dülmen, Theater des Schreckens. Gerichtspaxis und Strafrituale in der frühen Neuzeit (München, 1985); J.M. Beattie, Crime and the Courts in England 1660-1800 (New Jersey, 1986); E. Österberg, D. Lindström, Crime and Social Control in Medieval and Early Modern Swedish Towns (Uppsala, 1988); R.J. Evans, Rituals and Retribution. Capital Punishment in Germany 1600-1987 (Oxford, 1996).

18 W. Maisel, Sąownictwo miasta Poznania do konca XVI wieku (Poznań, 1961); idem, Poznańskie prawo karne do końca XVI wieku (Poznań, 1963).

19 Idem, 'Związki sądownictwa miejskiego z sądownictwem krolewskim w Polsce przedrozbiorowej', Czas - przestrzeń - praca w dawnych miastach: Studia ofiarowane Henrykowi Samsonowiczowi w sześćdziesiata rocznice urodzin, eds. A. Wyrobisz et. al., (Warszawa 1991), pp. 337-342.

${ }^{20}$ K. Kamińska, Sądownictwo miasta Torunia do połowy XVII w. na tle ustroju sadow niektorych miast Niemiec i Polski (Warsaw-Poznań-Toruń, 1980); idem, 'Prawo chelminskie w Toruniu (1233-1793)', Księga pamiatkowa 750-lecia prawa chelminskiego, ed. Z. Zdrojkowski (Torun, 1988), pp. 23-84. 
studied the penalties for various offences in the three main cities of Poland, Krakow, Lublin and Poznań, in the context of West European cities. ${ }^{21}$ Dariusz Kaczor analysed the penalties for criminal offences in Gdańsk. ${ }^{22}$ Daily life was explored in Silesia ${ }^{23}$ and Gdańsk. ${ }^{24}$ The cities not only of Poland but also of Western Europe have drawn the attention of Polish researchers. ${ }^{25}$ Investigating death in the urban space, Edmund Kizik discussed in some detail the death penalty, and its symbolic meanings. ${ }^{26}$ The already-mentioned M. Kamler studied sentences for theft, infanticide ${ }^{27}$ and the influence of recidivism over sentencing. ${ }^{28}$ There were also several works summarising the investigations. ${ }^{29}$

There are almost no works in Lithuanian historiography devoted to criminal law in the practice of a Magdeburgian court. The works of legal historians provide a comprehensive analysis of the legal content of Magdeburg Law, discussing separately criminal law, distinguishing types of offences and penalties, but not going further into

${ }^{21}$ M. Kamler, 'Kary za przestępstwa pospolite w dużych miastach Polski w drugiej połowie XVI i pierwszej połowie XVII wieku', Kwartalnik Historyczny, 3(101) (1994), pp. 25-39.

${ }^{22}$ D. Kaczor, 'Władza i przestępcy. Sankcje karne za przestępstwa kryminalne w Gdańsku XVI-XVIII wieku’, Mieszczaństwo gdańskie (Gdańsk, 1997), pp. 161-186; idem, Przestępczość kryminalna i wymiar sprawiedliwości w Gdańsku w XVI-XVIII wieku (Gdańsk, 2005).

${ }^{23}$ E. Maleczyńska, Życie codzienne Śląska w dobie Odrodzenia (Warsaw, 1973); R. Kiersnowski, Źycie codzienne na Ślasku w wiekach średnich (Warsaw, 1977).

${ }^{24}$ M. Bogucka, Życie codzienne w Gdańsku XVI-XVII wieku (Warsaw, 1967).

${ }^{25}$ H. Manikowska, Nadzór i represja. Władza i spoteczeństwo w późnośredniowiecznej Florencji (Warsaw, 1993).

${ }^{26}$ E. Kizik, Śmierć $w$ mieście hanzeatyckim $w$ XVI-XVIII wieku: studium $z$ nowożytnej kultury funeralnej (Gdansk, 1998).

${ }^{27}$ M. Kamler, 'Kary za kradzieź w Krakowie i Poznaniu w 2 połowie XVI wieku', Społeczeństwo staropolskie. Studia i szkice, vol. 4, ed. A. Izydorczyk, A. Wyczański (Warsaw, 1986), pp. 7-17; idem, 'Dzieciobójstwo w miastach Korony w drugiej połowie XVI i pierwszej połowie XVII wieku', Czasopismo PrawnoHistoryczne, nr. 1 (1986), pp. 171-184.

${ }^{28}$ Idem, 'Recydywa w przestępczości kryminalnej w Polsce drugiej połowy XVI i pierwszej połowie XVII wieku', Czasopismo Prawno-Historyczne, nr. 1-2, 1992 (1993), pp. 123-131.

${ }^{29}$ Idem, Świat przestępczy w Polsce XVI i XVII stulecia (Warsaw, 1991); idem, Złoczyńcy. Przestępczość w Koronie $w$ drugiej połowie XVI $i$ w pierwszej połowie XVII wieku (w świetle ksiag sądowych miejskich) (Warsaw, 2010). 
their practical application. ${ }^{30}$ The only topic in the investigation of which the issue of the death penalty on is touched is the daily life of the city, particularly Vilnius. For example, Stasys Samalavičius, in the popular booklet Vilniaus rotuše (Vilnius Town Hall), among other aspects of daily life in the capital, such as street life, trade and festivals, briefly discussed urban crime and its punishment. ${ }^{31}$ Jūratė Kiaupiene, in an article about Vilnius public life, also provided details about the penalties applied in the city. ${ }^{32}$ However, she did not use Magdeburgian, but the old Vilnius castle court books for her study. Aivas Ragauskas has analysed criminal law in the city of Vilnius somewhat. We can mention his works on the Vilnius executioner ${ }^{33}$ and the proceedings of the trial of Lukas Markovičius 'Mundijus'. ${ }^{34}$ J. Karpavičienè, in her monograph on the situation of the woman in Magdeburgian cities, analysed the opportunities for women in the courts of these cities. ${ }^{35}$ She also discussed the functioning of these rights during a trial. ${ }^{36}$ The main object of the research by Darius Antanavičius is the realisation of the decisions of the appeal courts, of the assessors and the relational courts, in the Magdeburgian courts of the first institution. ${ }^{37}$ There are materials reflecting the application of specific provisions of Magdeburg Law in practice, in a later period (the second half of the 17th and the 18th century) in the monograph by Vytautas Kryževičius. In addition

${ }^{30}$ V. Andriulis et. al., Lietuvos teisès istorija (Vilnius, 2002), pp. 106-110.

${ }^{31}$ S. Samalavičius, Vilniaus rotušè (Vilnius, 1981).

32 J. Kiaupienè, 'XVI a. Vilniaus viešojo gyvenimo vaizdai', Mūsu praeitis, t. 2 (Vilnius, 1992), pp. 15-29; eadem, 'XVI a. ikireforminio Vilniaus pilies teismo knygos-kopijos Lietuvos Metrikoje: struktūrinè ir informacinè analizè', Lietuvos Metrika. 1991-1996 metu tyrinejimai (Vilnius, 1998), pp. 36-92.

${ }^{33}$ A. Ragauskas, 'Vilniaus miesto budelis XVI-XVIII a.: institucija, amatas, žmogus', Šviesa (22 December 2006), p. 6.

34 Vilniaus Burmistro Luko Markovičiaus „Mundijaus“ kalbos, laiškai ir kiti raštai (1551-1584 m.), ed. A. Ragauskas, R. Ragauskienė (Vilnius, 2010), pp. xxxvii-li.

35 Karpavičienè, Moteris Vilniuje ir Kaune.

36 Eadem, 'Liubeko ir Magdeburgo teisių raiška Europoje viduramžiais ir ankstyvaisiais naujaisiais laikais', Acta Historica Universitatis Klaipedensis, t. 17 (2008), pp. 29-50.

${ }^{37}$ D. Antanavičius, 'Lietuvos Didžiosios Kunigaikštystès asesorių ir reliacijos teismų nutarimų vykdymas Kauno miesto taryboje XVI a. pabaigoje', Istorijos šaltiniu tyrimai, 5 (Vilnius, 2014), pp. 107-146. 
to personal liberty, property inheritance and issues of family law, he also touched on aspects of criminal law. ${ }^{38}$

Sources. The main sources of Magdeburg Law in Lithuania and Poland were Speculum Saxonum and Ius Municipale. In Poland, the Saxon mirror was published for the first time in 1506, in the acquis of Jan Łaski. ${ }^{39}$ The Polish lawyer Mikołaj Jaskier published the sources of Magdeburg Law in Latin as a separate work in $1535 .{ }^{40}$ This edition received the sanction of the king, with a recommendation for its use in all cities in which Magdeburg Law operated. ${ }^{41}$ About the middle of the 16th century there appeared editions of Magdeburg Law processed by Bartłomiej Groicki and adapted to Polish realities. ${ }^{42}$ Namely, sensing the lack of provisions in criminal law, he adapted for city law the criminal code of the Emperor Charles V, Constitutio Criminalis Carolina, published in $1532 .{ }^{43}$ Pawel Szczerbic translated into the Polish language the Saxon mirror and Ius Municipale in 1581. ${ }^{44}$ A. Ragauskas briefly reconstructed how these legal acts could be used in a court. ${ }^{45}$ In his opinion, in the subject index of Jaskier's Promptuarium, in which the legal terms were arranged in alphabetical order, the appropriate term

${ }^{38}$ V. Kryževičius, Lietuvos privilegijuotieji miestai (Vilnius, 1981), pp. 44-46, 55-57, 61-62, 97-99 et al.

39 J. Łaski, Commune incliti Polonie Regni privilegium constitutionum et indultuum publicitus decretorum (Cracow, 1506).

${ }^{40}$ N. Jaskier, Juris Municipalis Maideburgensis (Cracow, 1535).

${ }^{41}$ G. Kowalski, 'Ius municipale jako źródło prawa miejskiego i komponent staropolskiej kultury prawnej', P. Szczerbic, Jus Municipale, to jest prawo miejskie magdeburskie nowo z tacińskiego i niemieckiego języka z pilnościa $i$ wiernie przetoźone, ed. G.M. Kowalski (Cracow, 2011), s. xii.

${ }^{42}$ B. Groicki, Artykuly prawa majdeburskiego, które zowią Speculum Saxonum (1558); idem, Porzadek sądów i spraw miejskich prawa majdeburskiego w Koronie Polskiej (1559).

${ }^{43}$ Idem, Postepek sadów około karania na gardle (1559). In the research also was used the very Karolina - Karolina - ugolovno-sudebnoe ulozhenie Karla V, perevod S. Ia. Bulatogo (Alma-Ata, 1967).

${ }^{44}$ P. Szczerbic, Speculum Saxonum albo prawo saskie i magdeburskie porzadkiem abecadta z tacińskiego i niemieckich exemplarzów zebrane (Lwów, 1581); Jus municipale, to jest prawo miejskie magdeburskie nowo z tacińskiego i niemieckiego języka z pilnościa $i$ wiernie przełoźone (Lwów, 1581). In the research was used the latest edition of this book - P. Szczerbic, Jus municipale, to jest prawo miejskie magdeburskie nowo z łacińskiego $i$ niemieckiego języka z pilnością $i$ wiernie przełoźone, ed. G.M. Kowalski (Kraków, 2011).

${ }^{45}$ Vilniaus Burmistro Luko Markovičiaus ,"Mundijaus“ kalbos, p. XLVII. 
was found, and then, according to the references provided there, a search was made for specific articles in parts of Juris Provincialis quod Speculum Saxonum and Juris Municipalis Maideburgensis. As additional sources, the privileges granting Magdeburg Law to cities, ${ }^{46}$ in 1551 and 1620 the vilkieriai ${ }^{47}$ (jurors) of Vilnius city and the Third Lithuanian Statute were used in the study. ${ }^{48}$

The second group of sources are the books of Magdeburg city acts. They are identified as such in inventories of archives. The books of various city institutions come under this name. Moreover, in this period, every institution wrote all its documents of activities (minutes of meetings, actifications of documents, complaints, court records) in one book. Very few books have been preserved from the reference period. The archives of cities, including Vilnius, were destroyed or significantly damaged during the wars with the Russians and Swedes in the middle of the 17th century and the subsequent occupation. Moreover, over time, the books were reexamined again. Damaged parts were removed, and the remnants of books were bound together into one volume. In this way, the documents of several city institutions would end up in the same volume. Some of these books were published in the end of the late 19th and early-20th century in a series issued by the Vilnius Archaeographical Commission. These are one book from Mogilev in $1578-1579,{ }^{49}$ and a book of the Vilnius magistrate. ${ }^{50}$ However, in the published books of the magistrate of Vilnius, no decisions on criminal cases were found. A few years ago, in the series 'Privileges and Acts of the Magdeburgian Cities of Lithuania', one book of the Merkine court, covering the period 1598 to 1627 , was published. ${ }^{51}$ In recent years, one book of the Kaunas Council ${ }^{52}$ and one book of the court of the Kaunas voigt have been published, but no criminal cases were found in them

${ }^{46}$ Used in the research were the Magdeburg privileges of the cities published in collections of sources Lietuvos magdeburginiu miestu privilegijos ir aktai (hereafter - LMMPA), t. 1-8 (Vilnius, 1991-2013).

${ }^{47}$ Dubinski, Zbiór praw y przywilejów miastu stołecznemu, pp. 91-101, 174-181.

${ }^{48}$ Statut Vialikava Kniazstva Litoy̆skaga 1588 goda, Teksty. Davednik. Kamentaryi (Minsk, 1989).

${ }^{49}$ Akty, izdavaemye Vilenskoiu komissieiu dlia razbora drevnikh aktov (furtherAVAK), t. 39 (Vilnius, 1915).

${ }^{50}$ AVAK, t. 10 (Vilnius, 1879); t. 20 (Vilnius, 1893).

${ }^{51}$ Merkinés miesto aktai (1598-1627), ed. A. Baliulis, t. 7 (Vilnius, 2010).

52 Kauno miesto aktu knygos XVI-XVIII a. Tarybos knyga 1555-1564, ed. D. Antanavičius (Vilnius, 2013). 
also. Part of the book of Polotsk acts was published in Belarus. ${ }^{53}$ Individual cases in the first half of the 16th and the 17th century are published in various collections of sources. ${ }^{54}$ However, archival sources, the manuscript books of the courts, comprise the basis of the study. Z. Kiaupa, ${ }^{55}$ A. Baliulis ${ }^{56}$ and A. Tyla ${ }^{57}$ have discussed historical sources of former Magdeburgian cities in present-day Lithuania. However, the books of the courts of the Magdeburgian city of Mogilev (in present-day Belarus) comprise the most numerous group of archival sources. They are stored in the National Historical Archives of Belarus. The city received Magdeburg Law on 28 January 1577. This archival holding has 22 books from our period of research. ${ }^{58}$ Twenty of them are books of the courts of the Magistrate (general court of the burgomaster, councillors, benchers, and sometimes landvoigt), and two of the separate voigt and benchers court. The oldest of them is from 1579-1580. The second largest archive is that of the city of Kaunas, a total of 17 books. Of them, also only two, dated 1612-1621 and 1622-1640, belong to the court of the benchers. ${ }^{59}$ Eleven are from the voigt home court, the rest from the city council. ${ }^{60}$ The oldest book from 1522-1545 belonged to the council. ${ }^{61}$ Documents from Merkinè have survived well. It received the privilege on 7 December 1569. There are two surviving books, in which documents from 1598 are bound. From 1610 until 1629, the

53 Aktavaia kniga Polatskaga magistrata 1650 g., ed. M. Yu. Gardzeyeu (Minsk, 2006).

${ }^{54}$ Belaruski arkhiü, t. 1 (Minsk, 1927); Lietuvos Didžiosios Kunigaikštystès kasdienis gyvenimas, ed. A. Baliulis, E. Meilus (Vilnius, 2001); Raganu teismai Lietuvoje, ed. K. Jablonskis, R. Jasas (Vilnius, 1987).

55 Z. Kiaupa, 'Kauno miesto vaitas ir jo aktų knygos XVI-XVII a. pirmoje pusejje', LMIŠ (Vilnius, 1988), pp. 25-45; idem, 'Du aktai apie Kauno miesto archyvo nuostolius 1678 m. ir 1732 m.', ibid., pp. 146-159; idem, 'Kauno miesto senojo archyvo likimas', MADA, t. 2 (43), (1973), pp. 125-140.

${ }^{56}$ A. Baliulis, 'Trakų magistrato aktų knygos (iki XVIII a. pabaigos)', LMIŠ (Vilnius, 1988), pp. 46-59.

57 A. Tyla, 'Žemaitijos savivaldžių miestų dokumentai Lietuvos metrikoje', ibidem, pp. 5-24; idem, 'Vilniaus miesto dokumentai Lietuvos Metrikoje', LMIS̆, t. 3 (Vilnius, 2001), p. 15.

58 Natsional'nyi istoricheskii arkhiv Belorusi (NIAB) [National Historical Archives of Belarus], Mogilevskii magistrat, f. 1817, ap. 1.

${ }^{59}$ Book of the acts of the city of Kaunas $1610-1622$, VUB RS, f. 7, b. 13861; LVIA, SA, b. 13863.

${ }^{60}$ Kiaupa, 'Kauno miesto senojo archyvo likimas', pp. 125-139.

${ }^{61}$ Book of the acts of the city of Kaunas 1522-1545, VUB RS, f. 7, b. 13838. 
records from the voigt and benchers court are registered in them. ${ }^{62}$ Three books from the courts of Brest are known, from 1623-1626, 1637-1641 and 1642-1644. All of them belong to the court of the burgomaster and councillors. ${ }^{63} \mathrm{Up}$ to this day, one court book of the voigt and benchers' court of Vilnius from the researched period has survived, in which individual documents from 1491 are bound. There is also one book of the Magdeburgian institutions of Grodno for 1638-1644, in which a third of the records belong to the council's court, and two thirds to the voigt and benchers' court. ${ }^{64}$ Also, one book of the private magistrate of Kèdainiai, dated 1623, has been found. ${ }^{65}$ The Magdeburgian court books of Trakai, although indicated in the inventory from 1619, are actually from $1719^{66}$ and did not enter into the study. In order to better understand the significance to the investigation of the surviving books of the different courts, we will discuss the competencies of these courts.

\section{The competence of the Magdeburgian courts}

The functions of the city officials and courts of the Grand Duchy of Lithuania are not listed in the first Magdeburg charters. They developed over a long period. Moreover, as historians have already observed, although the same Magdeburg Law functioned, and the same bodies of local government and courts operated, their competence in individual cities was different. For example, in Vilnius, only in 1620 was the competence of every city court defined finally and strictly. ${ }^{67}$ The voigt was the head of the court of benchers. This court dealt with criminal cases and some minor civil cases. In major civil cases, the benchers were required to apply to the burgomaster and councillors. Magdeburg Law did not allow the voigt to express an opinion, or in any way affect the judgment of the court. He only formulated and announced the decision. There was also the voigt home court, which decided the everyday disputes of city residents. ${ }^{68}$

${ }^{62}$ Book of the acts of the city of Merkine, LVIA, SA, b. 5845, 5847. The first book is published, see footnote no. 51 .

${ }^{63}$ Brestskii magistrat, NIAB, f. 1786, ap. 1, b. 1-3.

${ }^{64}$ Grodnenskii magistrat, NIAB, f. 1761, ap. 1, b. 1-3.

${ }^{65}$ Book of the Kedainiai magistrate, LVIA, SA, b. 15357.

${ }^{66}$ Baliulis, 'Trakų magistrato aktų knygos', p. 51.

${ }^{67}$ Kiaupa, 'Vilniaus ir Kauno vaitu teisminès galios raida', pp. 83-90; idem, ' $1551 \mathrm{~m}$. ir $1620 \mathrm{~m}$. Vilniaus vilkieriai', pp. 41-51.

${ }^{68}$ This court decided simpler cases, most often on domestic issues. A. Baliulis has discussed in detail one Kaunas voigt book, 'Kauno miestiečių kasdienybè 
These courts also existed in Kaunas, Grodno and Brest. But from the second half of the 16th century, the competencies of the courts were already quite often specified in the Magdeburg privileges: the court of the voigt and the benchers was assigned criminal cases, and the court of the Council (burgomaster and councillors) civil cases; but in reality, not in all cities were these courts distinguished. As Rimša noted, in smaller towns, the benchers' court often became an appendix of the City Council. ${ }^{69}$ The fate for this court was formulated in the Magdeburg privilege for Merkine: 'Bloody affairs, which in Latin were called criminal, such as robbery, murder, bodily harm, arson and other similar things and deeds, for which the punishment is death, belongs to the voigt's court, answer to the voigt, the burgomaster, the benchers and the councillors. ${ }^{70}$ However, in reality, at the end of the 16th century the benchers were able to secede and establish a separate court there. The complete opposite situation occured in Mogilev. Here, in 1634, on the initiative of the ruler and the city voigt Aleksandras Liudvikas Radvila (Aleksander Ludwik Radziwill), the general court of the magistrate operating up till then, on the example of Vilnius, was separated into courts of the voigt and benchers, and of the burgomaster and councillors. ${ }^{71}$ However, after a couple of years, at the request of residents and the city government, due to the great confusion that arose, these courts were merged again, and later decided all cases together. ${ }^{72}$ In smaller towns, the duties of the voigt were often linked to the duties of the elder. For example, this happened in 1611 in Jurbarkas. ${ }^{73}$ If the ruler appointed the voigt in state Magdeburgian cities, then the owner of the city appointed him in the private ones. ${ }^{74}$ In the private

XVI a. antrojoje puseje (pagal Kauno miesto vaito 1561-1564 m. įrašų knygas)', Senoji Lietuvos literatūra, 34 knyga (Vilnius, 2012), pp. 185-219.

${ }^{69}$ E. Rimša, 'Merkinès suolininkų teismo ir antspaudų atsiradimo klausimu', Merkine, ed. A. Baliulis, LMMPA, t. 5 (Vilnius, 2007), p. 141.

${ }^{70}$ Knyszyn, 7 December 1569 privilege of GDL Zygmunt August to Merkine residents, granting them Magdeburg Law and other freedoms, ibid., p. 72.

${ }^{71}$ Mogilevskii magistrat, NIAB, f. 1817, ap. 1, b. 11, 1. 1-2.

72 Ibid., 1. 527.

${ }^{73}$ The granting of Magdeburg rights to the city of Jurbarkas, 4 November 1611, Joniškis, Jurbarkas, ed. A. Tyla, LMMPA, t. 1 (Vilnius, 1991), p. 227.

74 'The privilege of Jonas Karolis Chodkevičius, which granted Magdeburg Law to Kretinga, 23 January 1609', Kretinga, Skuodas, Šiauliai, Šventoji, Varniai, Veliuona, Viekšniai, Virbalis, Vladislavovas, ed. A. Tyla, D. Žygelis, LMMPA, t. 2 (Vilnius, 1997), p. 29. 
town of Skuodas, residents suggested three candidates, from whom the owner selected one. ${ }^{75}$ The bishop of Žemaitija appointed the voigt in Varniai. ${ }^{76}$ The voigt, together with the burgomaster and city council, had to decide all cases. Therefore, the most relevant books for the study were the books of the magistrate's court and those of the voigt, together with the benchers' court. In the books of the Council court and the voigt home court, we can find only random criminal cases. Considerably more complaints were registered for criminal offences or reconciliations in such cases.

Those who did not agree with the decisions of the city court were allowed to appeal. In Poland, the appeal usually went from one city to another, higher in rank, until it reached Cracow. In Cracow the highest Magdeburg Law court Iuris supremi Maydeburgensis operated. In some cases, enquiries on how to solve a case were possibly even sent to Magdeburg itself. In Lithuania, the highest instance of appeal was the assessors and relational courts. Members of the Senate usually comprised the assessors' court, while the ruler himself would join the relational court. ${ }^{77}$ However, not all the decisions of the city would immediately reach these courts. The residents of smaller cities would first of all appeal to the administrator of the nearest manor, or to the starosta. For example, the residents of Alytus had to appeal to the administrator of the ruler's Alytus manor, who, under Magdeburg Law had to decide the case. ${ }^{78}$ The townspeople of Lazdijai appealed to the starosta of Lazdijai, and then to the ruler. The residents of Simnas were allowed to appeal directly to the ruler. ${ }^{79}$ There was an interesting situation in Mogilev. Because nobles usually fulfilled the duties of the voigt, their deputies, the landvoigt, presided in the

75 'The writ of Wladyslaw Vasa, by which the ruler at the request of the Marshal of Lithuania, starosta of Slonim, and civun of Volpa and Luboshany Kazimieras Leonas Sapiega, confirms the privilege of Jonas Chodkevičius of 17 May 1572 to Skuodas, granting Magdeburg rights', ibid., p. 87.

76 Rimša, Lietuvos Didžiosios Kunigaikštystès miestų antspaudai, p. 553.

77 Vilniaus burmistro Luko Markovičiaus „Mundijaus“ kalbos, p. xxxvii.

78 'The privilege of Steponas Batoras, granting Magdeburg rights and various incomes as well as lands to the city of Alytus, Vilnius, 15 June 1581', Alytus, ed. A. Tyla, $L M M P A$, t. 4 (Vilnius, 2006), pp. 94-99.

79 'Warsaw, 2 January 1626, privilege of Zygmunt Vasa granting Magdeburg rights to the city of Simnas at the request of GDL Deputy Chancellor and starosta of Simnas Paulius Sapiega', Lazdijai, Simnas, ed. J. Drungilas, LMMPA, t. 8 (Vilnius, 2013), p. 157. 
court. Therefore, the appeal was first of all given to the voigt. ${ }^{80}$ The residents of private Magdeburgian cities would appeal to the owner of the city. However, in these towns, appeals in criminal cases were not always allowed. The owner himself decided this. For example, in the privilege of Kretinga, owned by Jonas Karolis Chodkevičius (Jan Karol Chodkiewicz), it was written: 'In criminal cases [those] sentenced to death without any appeal to us and our offspring, and in current cases appeals are allowed to the starosta. ${ }^{81}$ The same provision is in the privilege of Skuodas. ${ }^{82}$ In Varniai, there were appeals to the bishop in all cases. ${ }^{83}$

\section{The death penalty in sources of Magdeburg Law}

The death penalty in Latin sources of Magdeburg Law was defined as poena capitis, or poena mortis. In Polish texts, it is usually referred to as the na gardle (throat) sentence. However, in Magdeburg Law we can find other, less traditional, expressions. The death penalty is equated here with eternal exile: wieczne wygnanie (perpetual exile). ${ }^{84}$ It is also defined as a conviction lykiem (gulps) or powrozem (rope), ${ }^{85}$ which meant death on the gallows. In Magdeburg Law, the main function of the death penalty was to frighten, to deter potential criminals from crime, by demonstrating the brutality of the punishment. ${ }^{86}$ The severity of the punishment depended on several things. In the case of theft, the value of the object and the place from where it was stolen were important. Recurring, repeated offences aggravated the punishment. As did whether it was committed in the day or at night, planned, for profit, or spontaneous. The status of the victim and the perpetrator, or their family ties, also had an influence on the punishment. The main death penalties mentioned in sources of Magdeburg Law are beheading and hanging. Thieves were usually hanged. ${ }^{87}$ Beheading was stipulated for several

\footnotetext{
${ }^{80}$ Mogilevskii magistrat, NIAB, f. 1817, ap. 1, b. 2, 1. 515.

81 'Privilege of Jonas Karolis Chodkevičius', p. 28.

82 'The writ of Władysław Vasa', pp. 86-87.

83 'Charter of Władysław Vasa, which at the request of the Samogitian bishop and Senate, grants Magdeburg rights to Varniai, 14 March 1635', LMMPA, t. 2, p. 163.

${ }^{84}$ Szczerbic, Jus Municipale, art. xxxviii, p. 168.

${ }^{85}$ Ibid., art. xxxviii, p. 168.

${ }^{86}$ Ibid., art. i, p. 18.

${ }^{87}$ Speculum Saxonum ii.13; Szczerbic, Ius Municipale, art. cxv.
} 
offences: inciting unrest in the city, ${ }^{88}$ murder, ${ }^{89}$ daytime arson, ${ }^{90}$ marital infidelity, ${ }^{91}$ rape, ${ }^{92}$ the abduction of women. ${ }^{93}$ In addition, we can find a whole range of qualified death penalties, applied to more serious crimes. One of these penalties is the wheel. This is a death penalty carried out on a heavy, wrought iron wheel, for treason, ${ }^{94}$ theft from holy places (churches, monasteries, cemeteries), the abduction of draught animals, ${ }^{95}$ arson during the night, ${ }^{96}$ and planned murder in an ambush. ${ }^{97}$ For a planned murder, seeking to gain control over the property of the murdered, dragging by horses across a market square and the wheel beckoned. ${ }^{98}$ For the murder of her baby, a mother was to be buried alive and pierced with a stake. ${ }^{99}$ For arson, ${ }^{100}$ counterfeiting, ${ }^{101}$ witchcraft, ${ }^{102}$ sodomy and bestiality, ${ }^{103}$ burning was threatened. After Groicki supplemented the norms of Magdeburg Law with the norms of the acquis of Emperor Charles V Constititio Criminalis Carolina, punishments were in many cases differentiated by gender. For some crimes, murdering a baby, ${ }^{104}$ poisoning, ${ }^{105}$ and marital infidelity, ${ }^{106}$ the woman was to be drowned. Some of these punishments are also mentioned in the Magdeburg privileges of Lithuanian cities, granting the voigt and the benchers the right to decide criminal cases. For example, in the Magdeburgian charter issued to Veliuona by Grand Duke Alexander at the beginning of the 16th century it is written: 'The

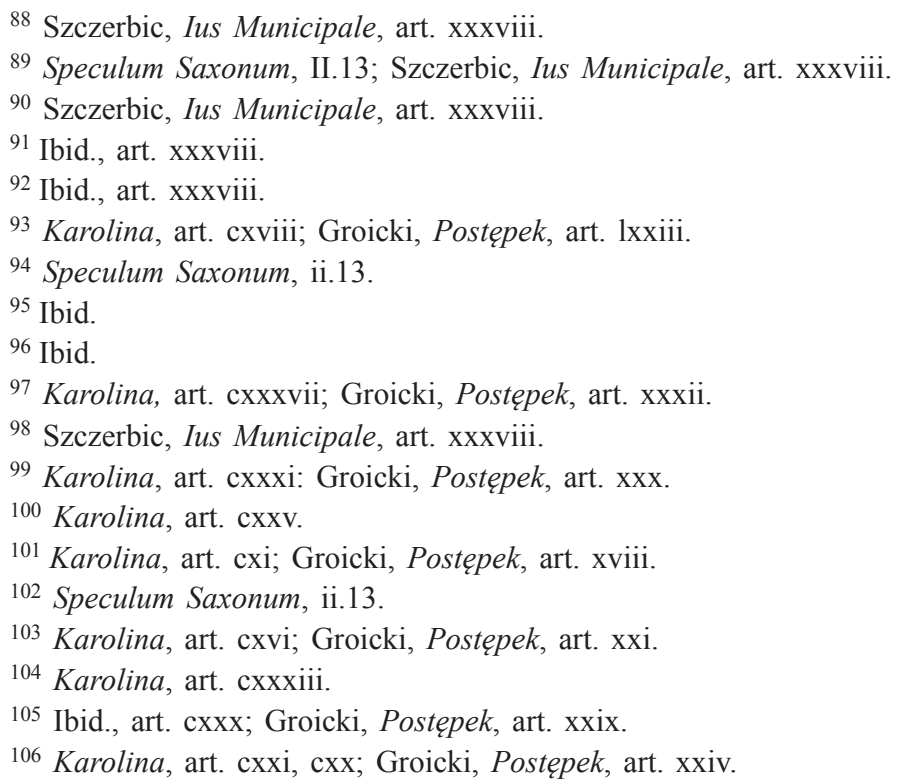


full right is granted to the voigt to try and convict, and punish and constrain in a straitjacket, and sit on a stake, and drown, in the way the Magdeburg Law of the Germans has and demands in all its sections.' 107 The charter granted by Steponas Batoras to Veliuona in 1507 also repeats this. ${ }^{108}$

\section{The death penalty in the practice of Magdeburg Law courts}

Punishment by hanging was the most frequent in the practice of Magdeburgian cities. In sources it is usually described as kara szubienicy (punishment of the gallows), obieszenie, or sometimes the broader term kara szyjej (neck punishment). Another term to describe it is karan jako złodziej (punished as a thief). It was applied for the most common crime in the city, theft, major or repeated. For minor thefts, corporal punishment was administered: being scourged at a pole, or sitting in the stocks. ${ }^{109}$ On 20 March 1625, in Merkine, the death penalty was given for nighttime burglary. ${ }^{110}$ Lukas Bedugnis (Łukasz Bedugnis) was charged with breaking into the storeroom of Anna Botkova (Anna Botkowa) in the night and stealing 120 groschen, nine sheepskins, rye flour and linen. He accused Jadvyga Varnelienè (Jadwiga Warnelowa) of complicity, she had allegedly persuaded him to steal, and took the stolen items from him. After torture and a confession, the court sentenced Bedugnis to death, and Jadvyga, accused for the first time, received an exculpatory oath with two joint oath makers. Often, the death penalty on the gallows was applied to horse thieves. ${ }^{111}$ Meanwhile, for robbery of holy places, unlike what was envisaged in legal acts, the punishment was not made more severe. For example, in June 1600, three Mogilev city residents were punished for robbing St Nicholas' Orthodox Church. All were sentenced to the gallows. The issue of a more severe punishment for them was not even discussed. ${ }^{112}$ Moreover, they were not allowed to buy their way out of their sentence. This punishment accounted for about a third of all executions in cities of the Grand Duchy of Lithuania. These figures are very similar to

\footnotetext{
${ }^{107} L M M P A$, t. 2, p. 178.

108 Ibid., p. 185.

${ }^{109}$ Acts of the city of Merkine, LVIA, SA, b. 5847, 1. 350, 406v.

${ }^{110}$ LMMPA. Merkinès miesto aktai, p. 830.

${ }^{111}$ Acts of the city of Merkine, LVIA, SA, b. 5847, 1. 620; AVAK, t. 39, p. 599.

112 Mogilevskii magistrat, NIAB, f. 1817 , ap. 1, b. 5, 1. 366-388.
} 
the number in neighbouring Poland, and even in Western Europe. For example, in Gdańsk, the sentence accounted for nearly a third of all penalties. ${ }^{113}$ In Nuremberg, throughout the 17th century it was 34\%, and in Frankfurt 63\%. ${ }^{114}$ Meanwhile, the overall number in Lublin, Poznań and Cracow exceeded 50\%. ${ }^{115}$ Testimonies 'in the last stage of life', when going to the gallows, had a symbolic meaning. During this time, it was still possible to withdraw testimonies against wrongly accused persons, while confirmation of testimonies was taken especially seriously. For example, in 1642 in Merkine, one of the brothers sentenced to be hanged for a major theft took advantage of this, to save his younger brother. 'On the last step of life,' he took all the blame on himself, exempting the youth from the charges. The punishment was executed, while the younger one's life was spared. He was whipped, branded on his shoulder, and was expelled from the city. ${ }^{116}$ A very similar case took place in 1624 in Mogilev. ${ }^{117}$ The death penalty on the gallows was replaced for minors by the same lighter penalty. ${ }^{118}$

Beheading (kara mieczom) was given for several crimes in Magdeburgian courts: murder, inciting riots and unrest, rape and adultery. A murder had to be unplanned, otherwise, according to the law, the mentioned qualified punishment threatened. However, Magdeburgian courts in Lithuania generally did not heed the difference fixed in these legal acts. I could not find a single case in the court records where a qualified death penalty was applied for murder. In all cases, beheading was given. However, there is one case in which a resident of the city of Mogilev was also sentenced to the penalty of the sword for the murder and robbery at night of a fellow traveller, but by the sentence, a proviso was recorded that another, more severe punishment threatened. And only in the light of his young age was it mitigated. ${ }^{119}$ It is not specified to what punishment. However, as I have already mentioned, according to Magdeburg Law, for planned murder, for profit, dragging by horses and the wheel threatened.

${ }^{113}$ Kaczor, 'Władza i przestępcy’, p. 171.

114 Dülmen, Theater des Schreckens, p. 110.

${ }^{115}$ Kamler, 'Kary za przestępstwa', p. 32.

${ }^{116}$ Acts of the city of Merkine, LVIA, SA, b. 5847, 1. 336.

${ }^{117}$ Mogilevskii magistrat, NIAB, f. 1817, ap. 1, b. 9, 1. 557.

${ }^{118}$ LMMPA. Merkinés miesto aktai, p. 413.

${ }^{119}$ Mogilevskii magistrat, NIAB, f. 1817, ap. 1, b. 5, 1. 440v. 
Rioting or inciting unrest expressed resistance to the city government, as did failure to carry out its resolutions, incitement to disobey and a direct attack on members of the council. This crime was sometimes equated to lèse-majesté. ${ }^{120}$ In September 1599, a resident of the city of Mogilev, Fyodor Denisovich, was accused of being a rebel and a destroyer of the social order. ${ }^{121} \mathrm{He}$ risked the death penalty, but it seems that it was not carried out, because a few months later he was again accused, only this time for breaking into a house, robbery and bodily injury. ${ }^{122}$ On 14 November 1613, in Merkine, Lukas Šurpa (Łukasz Szurpa), accused of inciting unrest, counterfeiting documents, promiscuity with another man's wife and other crimes, was beheaded. ${ }^{123}$

Rape in Magdeburg cities was quite a frequent crime, but the punishment for it was imposed very rarely, and even more rarely carried out. Specifically, I could not find a single case where the death penalty was executed for this. Even when the crime was clear, formal reasons were found for not carrying out the punishment. For example, in the autumn of 1610, in Merkine, a resident was sentenced to death for the rape of a girl, a relative. ${ }^{124}$ The court did not consider this incest, but recognised it as an aggravating circumstance. The convicted appealed to a higher court. However, even before the time of the appeal, the victim forgave him. In December 1621 the townswoman Darata Girnakaliūte (Dorota Girnokolówna) appealed to the court of Merkine through her representative Jonas Griškaitis (Jan Hryszkowicz), and accused Stanislovas Dombrovskis (Stanisław Dombrowski) of rape. ${ }^{125}$ As was required by law, they presented reliable witnesses who confirmed that they had heard her cries for help. After the court had assigned an investigation at the scene of the event, some witnesses confirmed that they had seen the girl being dragged by force into the storeroom, and others had heard her cry. One woman even testified that it was not the first attempt at rape by Dombrovskis. All the evidence was against the accused. The plaintiffs demanded that he be punished with the death penalty according to Article 38 of the Juris municipalis. However,

\footnotetext{
120 Vilniaus Burmistro Luko Markovičiaus „Mundijaus“ kalbos, p. xxxvi.

${ }^{121}$ Mogilevskii magistrat, NIAB, f. 1817, ap. 1, b. 5, 1. 86v.

122 Ibid., 1. 182.

${ }^{123}$ LMMPA, Merkines miesto aktai, pp. 510-515.

124 Ibid., p. 380.

${ }^{125}$ Ibid., p. 714.
} 
the defendant demanded that he be acquitted, on the basis of the same article. It turned out that all this evidence should have been presented immediately after the crime. In this case, a few days had passed. It turned out that Dombrovskis, probably aware of this provision, and in order to play for time, had promised compensation for the crime. The girl was tempted, and only a few days later, when she did not receive it, she turned to the court. The court, while stating that Dombrovskis was guilty according to the letter of the law, was forced to apply to him the exculpatory oath of the seven (the accused and six additional co-swearers, who had to guarantee the certainty of the oath). Of course, appeals followed such a decision. Both Dombrovskis and Darata made appeals. ${ }^{126}$ Unfortunately, the further course of the case is unknown.

Cases of adultery were proven more often. However, they also usually ended in reconciliation. For example, on 11 June 1640, in the book of the Brest council court, the complaint of the city's burgomaster Lukas Pomažanskis (Łukasz Pomarzanski) is recorded for the repeated infidelity of his wife Elizabeth (Helzbieta) and the serious intent to punish her. ${ }^{127}$ However, after a few months, the sides were again reconciled. ${ }^{128}$ The death penalty was usually imposed only after repeated infidelities, when the spouse grew tired of reconciling. This happened in March 1619 in Mogilev, when Ilja Onoprejewicz and Odarja Kozlewna were beheaded, after the court stated that after many pardons and guarantees, they deliberately did not want to give up their wicked habit. ${ }^{129}$ It is interesting that in this case the sentencing was not based on Magdeburg Law, but the Lithuanian Statute. Sometimes marital infidelity became a pretext for other crimes. For example, in 1642, Józef Zamorski, a resident of the city of Mogilev, was accused of the murder of his brother, but he would not admit to it. Then his extramarital relationship with the murdered man's wife was proven. Consequently, he was punished with the death penalty, not for murder, but for adultery, to which he admitted. ${ }^{130}$ What is interesting is that the unfaithful widow was not summoned to the court, either as a witness or as the accused.

\footnotetext{
126 Ibid., p. 715.

${ }^{127}$ Brestskii magistrat, NIAB, f. 1786, ap. 1, b. 2, 1. 641.

${ }^{128}$ Ibid., 1. 667.

${ }^{129}$ Mogilevskii magistrat, NIAB, f. 1817 , ap. 1, b. 8, 1. 449.

${ }^{130}$ Ibid., b. 13, 1. 621-627.
} 
Beheadings in the practice of Magdeburgian courts of the Grand Duchy of Lithuania accounted for about a quarter of all punishments. Meanwhile, in Gdansk, this death penalty comprised more than $60 \%$ of all death sentences. ${ }^{131}$ In Krakow, Poznan and Lublin together, about $30 \%,{ }^{132}$ in Frankfurt 29\%, and in Nuremberg 58\%. ${ }^{133}$

There were many abundant instances when the particular death penalty given by the court was not stated. It was also not said on the basis which legal acts it was pronounced. However, from the nature of the cases, we can decide that they were punishments by hanging or beheading, depending on the crime committed.

Punishment by burning in Magdeburgian courts of the Grand Duchy of Lithuania was generally given for witchcraft. There were not very many accusations of this crime, unlike in the castle or patrimonial courts, and they usually ended in reconciliation. In some cases, the result is unknown, because the cases were not concluded. However, on 27 February 1642, in Polotsk, a supposed wizard Vassily Brykun was burnt. As many as 12 people complained of his misdeeds, and another 27 testified that they had heard that he was a wizard. ${ }^{134}$ The oath of the accusers and witnesses determined the outcome of the case. The sentence was suspended until after the Easter holiday. While waiting for the punishment, Vassily committed suicide. Therefore, the judgment of the court was executed by burning his body. There were cases where the applicants themselves did not demand the death penalty. For example, on 27 April 1646, the enchantment case of the Merkine resident Martynas Velička (Marcin Wieliczkowicz) was discussed. ${ }^{135}$ The plaintiff did not demand the death penalty for the accused Magdalena. Therefore, she was whipped, had a mark burnt on her, and was driven from the city.

No punishment of burning for arson was encountered in the sources. For example, in September 1599, the Magdeburgian court of Mogilev considered the case of the burning of property worth 900 groschen. ${ }^{136}$ After the defendant explained that it had happened by accident, he was punished only with a fine of 40 groschen. In July 1600, in the same Mogilev, Demid Ivaskovich, while burning

\footnotetext{
${ }^{131}$ Kaczor, 'Władza i przestępcy’, p. 171.

132 Kamler, 'Kary za przestępstwa', p. 32.

133 Dülmen, Theater des Schreckens, p. 110.

${ }^{134}$ Raganu pilies teismai, pp. 45-47.

${ }^{135}$ Ibid., pp. 214-218.

${ }^{136}$ Mogilevskii magistrat, NIAB, f. 1817 , ap. 1, b. 5, 1. 100v.
} 
his garden, also burned down the house of his neighbour Agnieszka Isakova. The culprit went unpunished, because the victim went to court only asking for permission to live in the bathhouse that had survived the fire, the right to which her neighbour had challenged. ${ }^{137}$ Charges for other crimes (counterfeiting coins, homosexuality, bestiality), for which burning was the punishment, have not been found up to now in the books of the courts. Therefore, punishment by burning comprised scarcely $3 \%$ of all death sentences. However, this is only slightly less than the situation in Gdansk, for example, where the punishment amounted to $4.5 \%{ }^{138}$ Investigating this punishment in major Polish cities, Kamler did not include punishments for witchcraft in the total number of sentences, but even without them it comprised $4.2 \%$ of men and $5.6 \%$ of women. ${ }^{139}$ The penalty was applied more often in Sweden, especially to women. They could be punished with death at the stake for murder, infanticide, major theft and bigamy. ${ }^{140}$

\section{Death penalties}

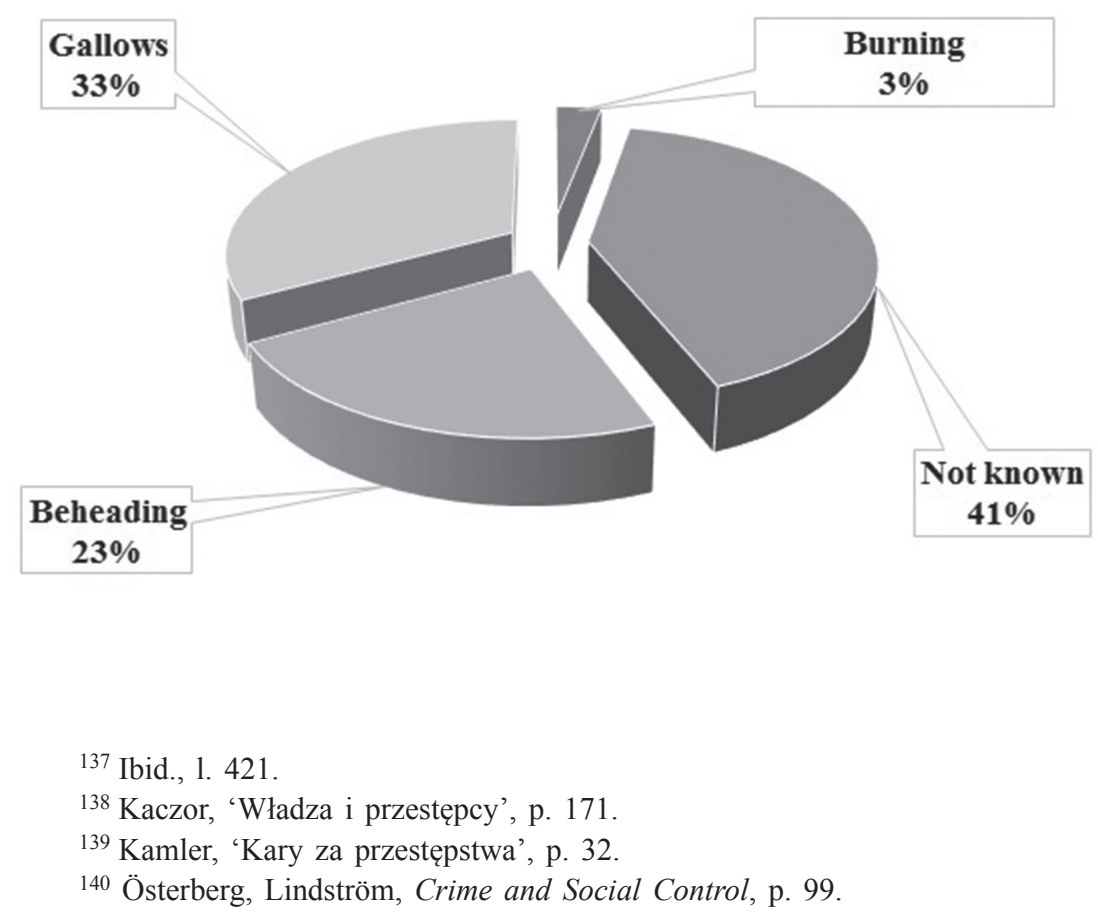


The application of other qualified punishments was not detected in the practice of the courts in cities of the Grand Duchy of Lithuania. As has already been mentioned, theft from sacred places was not distinguished, and it was punished with the gallows. Qualified murder was punished with beheading. Until now, in the books of the courts, infanticide, for which a particularly cruel death threatened, has not yet been encountered.

If we compare criminality by men and women, men comprised the largest part, $95 \%$, of the criminals sentenced to death. In all crimes, even witchcraft, they exceeded women. Only for marital infidelity were slightly more women than men punished with the death penalty.

\section{Ratio of crime and punishment}

The court operated a private complaint procedure where the plaintiff had to prove the guilt of the accused. Unfortunately, quite often he failed to do so. The main evidence was considered testimonies, injuries during instances of rape or attempted murder, and oaths. Having evaluated the initial testimony, the court would decide which side would swear. Torture to extract the truth was still used very rarely in this period and it increased only slightly in the middle of the 17 th century. The effort to prove the crime failed for a variety of reasons: a lack of witnesses, the absence of obvious injury, and the violation of court procedures. Sometimes the oath was given to the defendants for obscure reasons, or in some cases not specified at all. About half the charges which were brought before the court were proven. In some cases, for example, for already mentioned rape, proven crimes were much fewer. ${ }^{141}$ Even after the crime was proven, even though the death penalty threatened, it was not always applied. The death penalty for murder was sometimes changed to banishment and expulsion from the city. ${ }^{142}$ As I have already mentioned, sometimes the parties agreed to come to terms. ${ }^{143}$ There were cases when the offender merely escaped from prison, or was released. ${ }^{144}$ Often, after imposing the death penalty, the court allo-

\footnotetext{
141 AVAK, t. 39, p. 186.

${ }^{142}$ Acts of the city of Merkine, LVIA, SA, b. 5847, 1. 392v.

${ }^{143}$ LMMPA, Merkinès miesto aktai, p. 486.

144 Ibid., pp. 415, 449, 505.
} 
wed an appeal to a higher instance. Then the outcome of the case usually remains unknown.

\section{Reasons for not carrying out punishments}

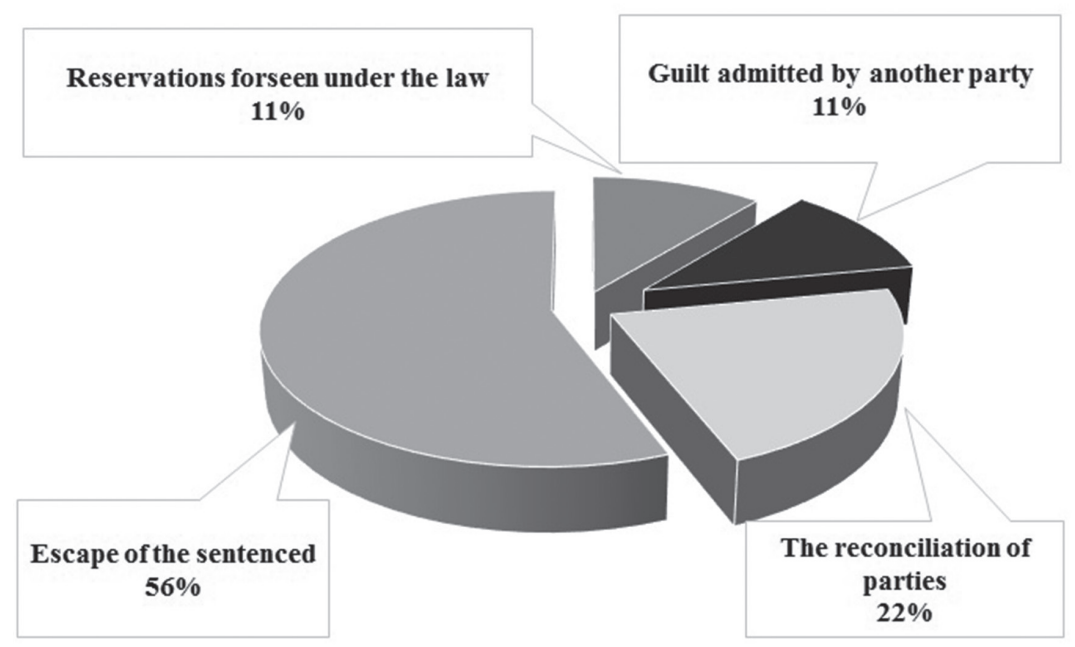

Penalties were imposed by Magdeburgian courts not only on city residents, but also on people from other social strata. These courts considered not only the complaints of the victims of city residents (the castle court did not accept such cases for consideration), but also the statements of city residents who were victims of the gentry or their subordinates. For example, on 13 October 1648, the Vilnius court of benchers imposed the death sentence on three noblemen for the disruption of public policy, shooting and injuring a person. ${ }^{145}$ Only, it seems, it was never carried out.

\section{Conclusions}

1. The court of the voigt and benchers heard criminal cases in the main Magdeburgian cities of the Grand Duchy of Lithuania. In others, where this court was unable to sit, they were considered jointly in the courts of the voigt and benchers, and of the burgomaster and councillors.

145 The book of the benchers' court of Vilnius, LVIA, SA, b. 5333, 1. 247. 
2. Cases were decided on the basis of Magdeburg Law Speculum Saxonum and Jus Municipale, and the publications of B. Groicki, adapted to local conditions. Sometimes there were also references to the Lithuanian Statute.

3. In the Magdeburgian cities of Lithuania, the most common crimes for which the death penalty was applied were theft, murder, inciting riots and unrest, marital infidelity, rape and witchcraft.

4. The most frequent death penalties imposed by the courts were hanging and beheading. There were isolated cases of burning. Other qualified penalties mentioned in the acts of Magdeburg Law were not encountered.

5. About half of all the penalties imposed were executed. Reasons for the failure to apply them included the escape of the convicted, reconciliation and young age. The outcome of a case often remains unknown, because one side made an appeal.

Author Details

Gitana Zujiene is a researcher in the Lithuanian Institute of History's Grand Duchy of Lithuania Department. Main research interests: auxiliary historical sciences (legal archaeology) and legal history.

E-mail: gzujiene@gmail.com

\section{References}

ANDRIULIS, V. et. al. Lietuvos teisés istorija (Vilnius, 2002).

ANTANAVIČIUS, D. 'Lietuvos Didžiosios Kunigaikštystès asesorių ir reliacijos teismų nutarimų vykdymas Kauno miesto taryboje XVI a. pabaigoje', in Istorijos šaltiniu tyrimai, 5 (2014).

BALIULIS A. 'Kauno miestiečių kasdienybė XVI a. antrojoje pusèje (pagal Kauno miesto vaito 1561-1564 m. įrašų knygas)', in Senoji Lietuvos literatūra, 34 (2012).

BALIULIS, A. 'Merkinès magistrato veikla XVI a. pabaigoje - XVII a. I pusèje', in Lituanistica, 3(53) (2007).

BALIULIS, A. 'Trakų magistrato aktų knygos (iki XVIII a. pabaigos)', in Lietuvos miestu istorijos šaltiniai, 1 (Vilnius, 1988).

BALIULIS, A. 'Traku miesto privilegijos (Lietuvos Metrikos duomenimis)', in Lietuvos miestu istorijos šaltiniai, 2 ed. Z. Kiaupa, E. Rimša, (Vilnius, 1992).

BARDACH, J. 'Miasta na prawie magdeburskim w Wielkim Księstwie Litewskim od schyłku XIV do połowy XVII stulecia', in Kwartalnyk historyczny, 1(87) (1980). 
BARDACH, J. 'Ustrój miast na prawie magdeburskim w Wielkim Księstwie Litewskim do połowy XVII wieku', in J. Bardach, $O$ dawnej $i$ niedawnej Litwie (Poznań, 1988).

BEATTIE, J.M. Crime and the Courts in England 1660-1800 (New Jersey, 1986).

BOGUCKA, M. Życie codzienne w Gdańsku XVI-XVII wieku (Warsaw, 1967).

Crime and the Law. The Social History of Crime in Western Europe since 1500, V. GATRELL, B. LENMAN, G. PARKER (eds.) (London, 1980).

DÜLMEN, R. van. Theater des Schreckens. Gerichtspaxis und Strafrituale in der frühen Neuzeit (München, 1985).

EVANS, R. J. Rituals and Retribution. Capital Punishment in Germany 1600-1987 (Oxford, 1996).

KACZOR, D. Przestepczość kryminalna $i$ wymiar sprawiedliwości $w$ Gdańsku w XVI-XVIII wieku (Gdańsk, 2005).

KACZOR, D. 'Władza i przestępcy. Sankcje karne za przestępstwa kryminalne w Gdańsku XVI-XVIII wieku’, in Mieszczaństwo gdańskie (Gdańsk, 1997).

KAMIŃSKA, K. 'Prawo chelminskie w Toruniu (1233-1793)', in Księga pamiatkowa 750-lecia prawa chelminskiego, Z. Zdrojkowski (ed.) (Toruń, 1988).

KAMIŃSKA, K. Sądownictwo miasta Torunia do połowy XVII w. na tle ustroju sadow niektorych miast Niemiec i Polski (Warsaw-Poznań-Toruń, 1980).

KAMLER, M. 'Dzieciobójstwo w miastach Korony w drugiej połowie XVI i pierwszej połowie XVII wieku', in Czasopismo Prawno-Historyczne, 1 (1986).

KAMLER, M. 'Kary za kradzieź w Krakowie i Poznaniu w 2 połowie XVI wieku', in Społeczeństwo staropolskie. Studia i szkice, 4, eds. A. Izydorczyk, A. Wyczański (1986).

KAMLER, M. 'Kary za przestępstwa pospolite w dużych miastach Polski w drugiej połowie XVI i pierwszej połowie XVII wieku', in Kwartalnik Historyczny, 3(101) (1994).

KAMLER, M. 'Recydywa w przestępczości kryminalnej w Polsce drugiej połowy XVI i pierwszej połowie XVII wieku’, in Czasopismo Prawno-Historyczne, 1-2(1992) (1993).

KAMLER, M. Świat przestępczy w Polsce XVI i XVII stulecia (Warszawa, 1991).

KAMLER, M. Złoczyńcy. Przestępczość w Koronie w drugiej połowie XVI $i$ w pierwszej połowie XVII wieku (w świetle ksiag sadowych miejskich) (Warszawa, 2010).

KARPAVIČIENĖ, J. 'Liubeko ir Magdeburgo teisių raiška Europoje viduramžiais ir ankstyvaisiais naujaisiais laikais', in Acta Historica Universitatis Klaipedensis, 17 (2008). 
KARPAVIČIENĖ, J. 'Magdeburgo teisè: ištakos ir transformacijos', in Lietuvos miestu istorijos šaltiniai, 3 (2001).

KARPAVIČIENĖ, J. Moteris Vilniuje ir Kaune XVI a. pirmojoje puseje. Gyvenimo sumiestinimo Lietuvoje atodangos (Vilnius, 2005).

KIAUPA, Z. '1408 m. Vytauto privilegija Kauno miestui', in Lietuvos istorijos metraštis, 1979 (1981).

KIAUPA, Z. '1551 m. ir $1620 \mathrm{~m}$. Vilniaus vilkieriai ir jų taikymas Lietuvos Didžiosios Kunigaikštystès miestuose', in Jaunujų istoriku darbai, 1 (1976).

KIAUPA, Z. 'Du aktai apie Kauno miesto archyvo nuostolius 1678 m. ir 1732 m.', in Lietuvos miestų istorijos šaltiniai, 1 (Vilnius, 1988).

KIAUPA, Z. 'Kauno miesto savivalda 1408-1508 m.', in Darbai ir dienos, 4 (1997).

KIAUPA, Z. 'Kauno miesto senojo archyvo likimas', in Lietuvos TSR Moksly Akademijos Darbai, A serija, 2(43), (1973).

KIAUPA, Z. 'Kauno miesto vaitas ir jo aktų knygos XVI-XVII a. pirmoje pusejje', in Lietuvos miestų istorijos šaltiniai, 1 (Vilnius, 1988).

KIAUPA, Z. 'Kauno savivaldos pradžia', in Mokslas ir gyvenimas, 1 (1989).

KIAUPA, Z. 'Lietuvos miestu savivalda XIV-XVIII a.', in Lietuvos heraldika, t. 1, ed. E. Rimša (Vilnius, 1998).

KIAUPA, Z. 'Miestai', in Lietuvos Didžiosios Kunigaikštijos kultūra. Tyrinejjimai ir vaizdai, ed. V. Ališauskas et. al. (Vilnius, 2001).

KIAUPA, Z. 'Miestietis, miesto pilietis ir miestenas', in Mokslas ir gyvenimas, 6 (1989).

KIAUPA, Z. 'Permainos Vilniaus savivaldoje XVI a. pirmojoje pusejje', in Vilniaus savivaldai 610 metu: mokslinès konferencijos pranešimu tezès (Vilnius, 1997).

KIAUPA, Z. 'Vaito rinkimas Kauno magistrate (XVI-XVIII a.)', in Lietuvos istorijos metraštis, 1974 (1976).

KIAUPA, Z. 'Vilniaus ir Kauno vaitų teisminès galios raida XV-XVII amžiais', in Lietuvos TSR mokslu akademijos darbai. Serija A, 4 (1974).

KIAUPIENĖ, J. 'XVI a. ikireforminio Vilniaus pilies teismo knygos-kopijos Lietuvos Metrikoje: struktūrinè ir informaciné analizè', in Lietuvos Metrika. 1991-1996 metu tyrinejimai (Vilnius, 1998).

KIAUPIENĖ, J. 'XVI a. Vilniaus viešojo gyvenimo vaizdai', in Mūsu praeitis, 2 (1992).

KIERSNOWSKI, R. Źycie codzienne na Ślasku $w$ wiekach średnich (Warszawa, 1977).

KIZIK, E. Śmierć w mieście hanzeatyckim w XVI-XVIII wieku: studium z nowożytnej kultury funeralnej (Gdansk, 1998).

KOPYSKII, Z.Y. 'Magdeburgskoe pravo v gorodakh Belorussii (konec XV - pervaia polovina XVII v.)’, in Sovetskoe slavianovedenne, 5 (1972). 
KOWALSKI, G. 'Ius municipale jako źródło prawa miejskiego i komponent staropolskiej kultury prawnej', in P. Szczerbic, Jus municipale, to jest prawo miejskie magdeburskie nowo z łacińskiego i niemieckiego języka z pilnościa i wiernie przełoźone, ed. G. M. Kowalski (Kraków, 2011).

KRYŽEVIČIUS, V. Lietuvos privilegijuotieji miestai (Vilnius, 1981).

Lietuvos Didžiosios Kunigaikštystès kasdienis gyvenimas, ed. A. Baliulis, E. Meilus (Vilnius, 2001).

MAISEL, W. 'Związki sądownictwa miejskiego z sądownictwem krolewskim w Polsce przedrozbiorowej', in Czas - przestrzeń - praca $w$ dawnych miastach: Studia ofiarowane Henrykowi Samsonowiczowi $w$ sześćdziesiąta rocznice urodzin, A. Wyrobisz et. al. (eds.) (Warsaw, 1991).

MAISEL, W. Poznanskie prawo karne do końca XVI wieku (Poznań, 1963).

MAISEL, W. Sadownictwo miasta Poznania do konca XVI wieku (Poznań, 1961).

MALECZYŃSKA, E. Życie codzienne Śląska $w$ dobie Odrodzenia (Warsaw, 1973).

MANIKOWSKA, H. Nadzór i represja. Władza i społeczeństwo $w$ późnośredniowiecznej Florencji (Warszawa, 1993).

MISAREVIČ, N.V. Magdeburgskaje prava na Belarusi (Grodno, 2003).

MORZY, J. Geneza i rozwój cechów wileńskich do końca XVII w. (Poznań, 1959).

ÖSTERBERG, E., LINDSTRÖM, D. Crime and Social Control in Medieval and Early Modern Swedish Towns (Uppsala, 1988).

Raganu teismai Lietuvoje, ed. K. Jablonskis, R. Jasas (Vilnius, 1987).

RAGAUSKAS, A. 'Iš XVII a. Vilniaus miestiečių valdančiojo elito istorijos: Motiejus Vorbekas-Lettowas (1593-1663) ir jo „Atminties lobynas"،, in Lietuvos istorijos metraštis 1996 (1997).

RAGAUSKAS, A. 'Ką reiškè terminas "patricius” XVII a. Vilniuje?' in Tarp istorijos ir būtovès. Studijos prof. Edvardo Gudavičiaus 70-mečiui, ed. A. Bumblauskas, R. Petrauskas (Vilnius, 1999).

RAGAUSKAS, A. 'Renkamos Vilniaus vaitijos genezè: XVI a. pabaiga ar XVII a. pradžia', in Istorija, 57 (2003).

RAGAUSKAS, A. 'Vilniaus miestiečių valdančiojo elito dalyvavimas seimuose XVII a. antrojoje pusejje', in Lituanistica, 4 (1998).

RAGAUSKAS, A. 'Vilniaus miesto budelis XVI-XVIII a.: institucija, amatas, žmogus', in Šviesa (22 December 2006).

RAGAUSKAS, A. Vilniaus miesto valdantysis elitas XVII a. antrojoje puseje (1662-1702) (Vilnius, 2002).

RIMŠA, E. 'Merkinès suolininkų teismo ir antspaudo atsiradimo klausimu', in Lietuvos miestu istorijos šaltiniai, 1 (Vilnius, 1988).

RIMŠA, E. Heraldika. Iš praeities $i$ dabarti (Vilnius, 2004).

RIMŠA, E. Kauno miesto herbas XV-XX a. (Vilnius, 1994).

RIMŠA, E. Lietuvos Didžiosios Kunigaikštystès miestu antspaudai (Vilnius, 1999). 
RIMŠA, E. Pieczacie miast Wielkiego Ksiestwa Litewskiego (Warszawa, 2007).

SAMALAVIČIUS, S. Vilniaus rotušè (Vilnius, 1981).

SHARPE, J.A. Crime in Early Modern England 1550-1750 (London, 1984).

TYLA, A. 'Žemaitijos savivaldžių miestų dokumentai Lietuvos metrikoje', in Lietuvos miestu istorijos šaltiniai (1988).

TYLA, A. 'Vilniaus miesto dokumentai Lietuvos Metrikoje', in Lietuvos miestų istorijos šaltiniai, 3 (2001).

TSITOŬ, A. Geral'dika belaruskikh mestaŭ (Minsk, 1998).

URBAITYTĖ, R. 'Kauno amatininkų cechų susikūrimas XVI-XVIII a.', in Kauno istorijos metraštis, 3 (2002).

URBANAVIČIUS, A. 'Imigracija i Vilnių iš Alytaus XVII a. 2-oje pusèje - XVIII a.', in Alytaus miesto istorijos fragmentai, A. Jakunskienè (ed.) (Alytus, 2001).

URBANAVIČIUS, A. 'Immigration to Vilnius from the Cities around the Baltic 1663-1795', in Tagungen zur Ostmitteleuropa-Forschung, 21: Riga im Prozeß der Modernisierung: Studien zum Wandel einer Ostseemetropole im 19. und frühen 20. Jahrhundert (Marburg, 2004).

URBANAVIČIUS, A. 'Iš Vilniaus miesto tarybos raštinès palikimo: naujųų miestiečių aktai 1663-1795', in Lituanistica, 4 (2001).

URBANAVIČIUS, A. 'Kauniečių kilmès Vilniaus naujieji miestiečiai 1661-1795 m.', in Kauno istorijos metraštis, 7 (2006).

URBANAVIČIUS, A. 'New Citizens of Vilnius 1661-1795', in Lithuanian Historical Studies, 10 (2006).

URBANAVIČIUS, A. 'The new citizens of Vilnius from Polish Royal Prussia', in Europa Orientalis. Studia z Dziejów Europy Wschodniej $i$ Państw Battyckich, 1 (Toruń, 2009).

URBANAVIČIUS, A. Vilniaus naujieji miestiečiai 1661-1795 m. (Vilnius, 2005).

URBANAVIČIUS, A. Vilniaus naujieji miestiečiai 1661-1795 metais. Sąrašas (Vilnius, 2009).

VARSACKYTĖ, R. 'Kauno miesto valdžios žmonės XVII-XVIII a. sandūroje', in Kauno istorijos metraštis, 5 (2004).

Vilniaus Burmistro Luko Markovičiaus „,Mundijaus “ kalbos, laiškai ir kiti raštai (1551-1584 m.), ed. A. Ragauskas, R. Ragauskienè (Vilnius, 2010). 
MIRTIES BAUSMĖ LIETUVOS DIDŽIOSIOS KUNIGAIKŠTYSTĖS

MAGDEBURGINIUOSE MIESTUOSE

XVI A. PABAIGOJE - XVII A. PIRMOJE PUSÉJE

Santrauka

GITANA ZUJIENE

Pastaraji dešimtmetị Lietuvos istoriografijoje pastebimas intensyvesnis domèjimasis magdeburginių teismų darbo praktika ir šios praktikos rezultatais, ị tyrimų akiratị vis dažniau patenka šių teismų knygos. Analizuojamos ịvairios temos, pradedant miestų kasdieniu gyvenimu, moterų teisine padètimi miestuose, baigiant baudžiamaja teise. Šio straipsnio tikslas - remiantis Lietuvos Didžiosios Kunigaikštystės magdeburginių teismų knygomis, aptarti mirties bausmę LDK magdeburginiuose miestuose, išsiaiškinti, už kokius nusikaltimus kokios bausmès buvo skiriamos, kokiais teisès aktais jas skiriant remtasi. Taip pat aptarti mirties bausmès ịvykdymo problemą.

Tyrime naudoti magdeburginès teisès šaltiniai Speculum Saxonum, Ius Municipale bei atskiri Constitutio Criminalis Carolina straipsniai bei daugiausia rankraštinès teismų knygos, saugomos Lietuvos ir kaimyninès Baltarusijos archyvuose. Tyrimas atskleidè, kad kriminalines bylas didžiuosiuose LDK magdeburginiuose miestuose (Vilniuje, Kaune, Breste, Gardine) sprendè vaito ir suolininkų teismas. Kituose, kur šis teismas ị atskirą nepajėgė išsiskirti (kaip pavyzdžiui, Mogiliave), jos buvo svarstomos bendrai vaito ir suolininkų bei burmistro ir tarejjų. Bylos buvo sprendžiamos ne tik remiantis magdeburginès teisès aktais Speculum Saxonum ir Jus Municipale, adaptuotais vietos sąlygoms. Kartais vadovautasi Lietuvos Statutu. Lietuvos magdeburginiuose miestuose dažniausi nusikaltimai, už kuriuos skirtos mirties bausmès, buvo vagystės, nužudymai, maištų ir neramumų kẻlimas, santuokinė neištikimybė, išprievartavimas, raganavimas. Dažniausiai teismų skirtos mirties bausmès - pakorimas ir nukirsdinimas. Pasitaikydavo pavienių sudeginimo atvejų. Kitų magdeburginès teisès aktuose minimų kvalifikuotų bausmių neaptikta. Ivvykdoma buvo maždaug pusė visų skirtų bausmių. Pagrindinès neįvykdymo priežastys buvo nuteistojo pabėgimas, šalių susitaikymas, bausmès perėmimas. Bausmė būdavo švelninama nepilnamečiams. Taip pat bylos baigtis dažniausiai lieka nežinoma kuriai nors šaliai pateikus apeliaciją. 